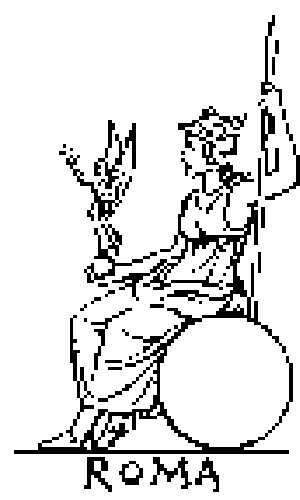

The Site of the Battle of Pharsalia

Author(s): J. P. Postgate

Source: The Journal of Roman Studies, Vol. 12 (1922), pp. 187-191

Published by: Society for the Promotion of Roman Studies

Stable URL: http://www.jstor.org/stable/296187

Accessed: 18/06/2014 15:29

Your use of the JSTOR archive indicates your acceptance of the Terms \& Conditions of Use, available at http://www.jstor.org/page/info/about/policies/terms.jsp

JSTOR is a not-for-profit service that helps scholars, researchers, and students discover, use, and build upon a wide range of content in a trusted digital archive. We use information technology and tools to increase productivity and facilitate new forms of scholarship. For more information about JSTOR, please contact support@ jstor.org. 


\section{THE SITE OF THE BATTLE OF PHARSALIA.}

By J. P. POSTGATE.

The long and heated controversy on the site of the great battle seems drawing to a conclusion. The disquisitions of Dr. Rice Holmes first in the Classical Quarterly ii (1908) pp. 27I-292, and secondly, improved and strengthened, in the third volume of his 'Roman Republic' (1923) pp. 452-467, and the topographical researches and arguments of Mr. F. L. Lucas, Annual of the British School at Athens, no. xxiv, pp. 34-53, have shown, I think, beyond cavil that it was fought on the north side of the Enipeus and that the theories of Leake, Mommsen, Heuzey, Stoffel, Kromayer and other advocates of a site to its south may be dismissed again to the obscurity from which they never should have emerged. Of these the reconstruction of Colonel Stoffel I887 (against which I vainly protested in $1896,{ }^{1}$ as Dr. Holmes records), had the longest reign, as might have been expected from the imposing confidence of its author and the excellence of the plans and views in his atlas. Sir Wm. Napier in Long's Decline of the Roman Republic, v, 220 sq., General von Göler, I880, and Mr. B. Perrin, I885 (American Fournal of Philology, vi, pp. I70-I89) had maintained that the battle could not have been fought to the south of the river; but the self-sufficient French Colonel knew or cared nothing about their contentions. The schemes of the two experts were vitiated by the lack of trustworthy maps; but Mr. Perrin's presentation of his results 'that the camps both of Pompey and Caesar were on the side of the Enipeus toward Larissa and that the camp of Pompey was on the southern slope of the hills bounding the northern edge of the Pharsalian plain "2 needed but a little precision in details to bring it into exact accord with the most recent investigations.

I do not here propose to traverse the same ground as Dr. Holmes and Mr. Lucas ${ }^{3}$; but to comment on a few details where there is still room for doubt or dispute to fasten. No solution of the problem is likely to be permanently satisfying which does not bring into essential harmony, on the one hand, the features and topography of the selected site and, on the other hand, the literary evidence

\footnotetext{
1 'As Col. Stoffel's theory must be rejected and as strategical reasons imperatively forbid the assumption of a site in the open south of the Little $\tau$ cbinarli it only remains to suppose that Pompey's camp was somewhere on the range of hills to the north of the plain and that the battle was thus
}

fought between them and the river.' Historical Introduction to my edition of Lucan vii, p. xxxvii. 2 Op. cit. p. 183 .

${ }^{3}$ I shall assume that the two discussions with the maps accompanying them are accessible to my readers. 
in its two divisions, the narrative of Caesar and what for brevity we may sum up as the extra-Caesarian sources.

\section{The Enipeus and the riuus of Caesar.}

The first stumbling-block (and a serious one) was that the stream appearing in all accounts of the engagement is given as the Enipeus, a river of note, in extra-Caesarian sources (Frontinus, Lucan, Appian and, as we can hardly doubt, in the lost book of Livy) but is in Caesar an unnamed streamlet, riuus quidam. The trouble is aggravated by the circumstance that the stream which flowed by the hill on which the Pompeians made their last stand is called a flumen, and we know that in normal Latinity riuus and flumen were opposed 'e riuo flumina magna facis' Ovid. ex Pont. ii, 5, 22. Dr. Holmes, who has examined with characteristic thoroughness the usus loquendi of Caesar in naming rivers came at first to the conclusion (C.Q. p. 280) that Caesar would have 'given to this famous river its familiar name.' In his later discussion (op. cit. 460) he says this argument 'was unsound. The Aternus, which Caesar omitted to mention in connexion with his blockade of Corfinium, was a considerable stream.' Caesar might indeed refrain from giving his readers the name of a flumen no further off than Corfinium was from Rome. But it was quite otherwise with a stream in the middle of a foreign land. We must conclude either that, when Caesar wrote, he did not know the name of the stream or that, if he knew it, he had some reason which we cannot now fathom for declining to mention it. The reason alleged by the commentators that on that summer day the famous river was only a trickle in its bed may excuse the riuus of the narrator but does not altogether account for it. If here the difficulty (I call it no more) remains as it was, on another side it has been distinctly alleviated. Mr. Lucas' identification of the flumen with the Kapakli river, provides us with a stream with a considerable volume of water in it at times when the Enipeus would be nearly dry (Holmes, p. 467, vol. 2). Some stress too may fairly be laid on the expression of the military chronicler Frontinus, ii, 22, who says that Pompey placed 600 horse 'propter flumen Enipea qui et alueo suo et alluuie regionem impedierat.' For the expression ' the river's bed' will attain a new pertinence if at the time of the battle the river itself was insignificant. There are other words in this sentence that will repay our closer scrutiny: impedierat recalls the impeditis ripis of Caesar, which is generally understood of the precipitous banks of his ' riuus,' resembling the precipitous banks of the Genusus

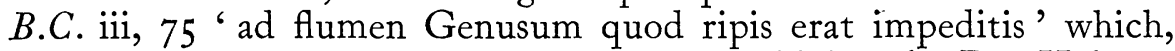
Stoffel notes, are from six to seven metres high. As Dr. Holmes, p. 454 , however, is aware, the word need not be thus limited, but may cover other obstacles to movement such as those of the "palus difficilis atque impedita' B.G. vii, I9.I or of the 'siluae impeditae' 
ib. $\mathrm{v}, \mathbf{2 1}, 3$. And here in close agreement, as would appear, with the facts it is used of two kinds of hindrances. Alluuie too demands attention. The word, a fairly rare one, is used by Livy (i, 4,5$)^{1}$, and Frontinus may have taken it from his account. Both it, as may be seen from the passage of Livy, and the 'stagna undantis Eripei' of Lucan vii, 224 as well as the 'paludibus' on which Frontinus says Caesar's left wing rested, imply the presence of a good deal more water on the scene than the English 'swamp' suggests or than some of the commentators seem to have realized. I have suggested that the storm of which Lucan gives a lurid account in vii, 653 sqq. may have been more than poetical ornament. The neighbourhood of the river may still have been flooded from the torrential rain, though its actual stream had shrunk to small dimensions. In concession to Dr. Holmes, I would now allow that the somewhat obscure undantis of Lucan need not mean that the Enipeus was a raging torrent at the time of the battle, but only when the stagna were formed. Then Lucan and Frontinus will be in substantial agreement. In conclusion I would say that what Mr. Lucas tells us (Holmes, p. 464, n. 2) that the ground between Mount Dogantzes and the neighbourhood of Kontouri must once have been marshy-it is still intersected by ditches full of water-. is a fact of first-rate importance.

\section{The Camps of Pompey and Caesar.}

Pompey's camp was on a hill-whether on its summit or its slopes Caesar's words ' castra in colle habebat' ch. 85, I, do not inform us. This 'collis' or 'mons,' as Caesar also calls it, Mr. Lucas, followed by Dr. Holmes, identifies with Mount Dogantzes which, with the Enipeus, all but closes the Pharsalian plain on the north-west. Appian (B.C. ii, 65) says that the distance between the camps was 30 stades (less than $3 \frac{\text { T}}{2}$ English miles). Dr. Holmes and Mr. Lucas ${ }^{2}$ call Appian a bad geographer, and it is tolerably certain that he did not distinguish the old Pharsalus (which had long ago disappeared) from the new. But he used good Roman authorities (ii, 7I); and the statement in question has nothing to do with 'geography.' Accepting it then, as we should, without hesitation, it would warrant us in placing the camp of Caesar in the neighbourhood of Kontouri which Heuzey and Mr. Lucas identify with Old Pharsalus or Palaepharsalus. ${ }^{3}$

\footnotetext{
1 'In proxima alluuie.' The 'eluuie' of many editors is without authority.

2 'A bad geographer' Holmes, p. 456. ' Geographically so disreputable,' Lucas, p. 36 .

${ }^{3} \mathrm{Mr}$. Lucas names this place Palaiopharsalos, an innovation which is neither good Greek nor
}

good Latin. The Greek is $\Pi a \lambda a \iota \phi d \rho \sigma a \lambda o s$ (or II $a \lambda a \iota a ̀ ~ \Phi a ́ p \sigma a \lambda o s)$, like $\Pi a \lambda a i \beta v \beta \lambda o s, ~ \Pi a \lambda a \iota$ -

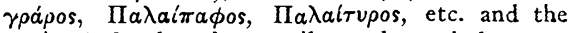
Latin Palaepharsalus, until we descend down to Eutropius in the fourth century A.D. 
Dr. Holmes, in the course of his argument against Kromayer (p. 460), contends that the words of Caesar ch. 85, 'ad infimas radices montis aciem instruebat, semper, ut uidebatur, exspectans si iniquis locis Caesar se subiceret' do not mean that Pompey had previously been drawing up his lines at the foot of the hill and therefore in the plain, but on the slopes of the hill. And on p. 46I he says "If Caesar had meant what Kromayer says, would he not have written sub ipsis radicibus montis ?' For support he appeals to B.G. i, 21, I ('certior factus hostes sub monte consedisse milia passuum ab ipsius castris octo'); 48, I ('castra promouit et milibus passuum sex a Caesaris castris sub monte consedit) and B.C. i, 45, 6 (" quod sub ipsis radicibus montis constiterant'). Dr. Holmes has however overlooked an important difference. In all the passages which he cites there is a movement along a plain towards a height above it, and hence sub is the proper preposition to use, $\mathbf{1}$ but here, where we start with a height ad 'near' is unimpeachable while sub would have been unusual and indeed almost absurd. Owing to this error Dr. Holmes, in his map (a modification of Heuzey's), has placed the battle lines of Caesar and Pompey in the actual engagement much too close to the mountain, Pompey's right wing in fact being made to rest on its slopes; and thus the phrase of Caesar 'animaduersum est paulo ante extra cottidianam consuetudinem longius a vallo esse aciem Pompei progressam ut non iniquo loco posse dimicari uideretur' (ch. 85,3 , compare the parallel expression of ch. 84, 2 ' paulo a castris Pompei longius' which must mean much the same) loses most of its meaning. Mr. Lucas, who puts Pompey's Camp by preference (he does not speak with certainty) on 'the south-east foot of Dogantzes' (p. 5I), takes the battlefield much further out along the plain; in fact nearer to Palaepharsalus than to Dogantzes. Certainty is not attainable, as Caesar's longius is far from precise; but I should conjecture that the truth lay between Dr. Holmes' and Mr. Lucas' assignments.

\section{Lucan vii, $2 \mathrm{I} 4$ sqq.}

Miles ut aduerso Phoebi radiatus ab ictu descendens toto perfudit lumine colles, non temere immissus campis stetit ordine certo infelix acies.

On this I wrote in 1896 (op. cit. p. xxxviii, n. 2). 'Nothing can be inferred... from Lucan's epithet aduerso in $v$. 214.' I thought then that it was only a part of the poet's mise en scene and of no more interest to the historian than the moonshine which illumined the 
floating corpse of Pompey (viii, 72I, and the note on p. lxi of my edition). But I was wrong. The reflexion of the morning sunlight from the weapons of the Pompeian army, as it descended, on to the neighbouring hills, is exactly what, as we may now see from the maps of Stoffel, Heuzey and Mr. Lucas, would be cast from a body of troops moving eastward from Mount Dogantzes into the Pharsalian plain; and it furnishes a very welcome confirmation of the solution of the problem which we have seen on other grounds to be acceptable. 